\title{
Biocontrol of Sweet Melon Fruit Rot Caused by Fusarium solani using an Endophytic Fungus Isolated from the Medicinal Plant Solenostemma arghel
}

\author{
Fatma F. Abdel-Motaal ${ }^{1,2, *}$, Noha M. Kamel ${ }^{1,2}$, Magdi A. El-Sayed ${ }^{1,3}$, Mohamed \\ Abou-Ellail $^{4}$ \\ ${ }^{1}$ Botany Department, Faculty of Science, Aswan University, Aswan 81528, Egypt ${ }^{2}$ Unit of Environmental Studies and Development, Aswan \\ University, Aswan 81528, Egypt ${ }^{3}$ Molecular Biotechnology Program, Faculty of Advanced Basic Sciences, Galala University, New Galala \\ City, Egypt, ${ }^{4}$ Department of genetics, Faculty of Agriculture and Natural Resources, Aswan University, Aswan81528, Egypt.
}

Received: July 27, 2020; Revised: October 3, 2020; Accepted: November 21, 2020

\begin{abstract}
The fruit rot disease of sweet melon is responsible for serious of economic crop losses that have occurred sporadically in Aswan, Egypt recently. The symptoms appeared as water-soaking lesion which advanced to the rotting of the fruit surface. White mycelial mats with brown color inside appear on the lesion at the surface of the fruit. Disease symptoms, morphological and mycological characteristics, pathogenicity and molecular identification, indicated as Fusarium solani, are the disease causative. When healthy fruits of sweet melon sprayed with spore suspension of the isolated F. solani, the disease symptoms appeared as white spot, which enlarged and turned brown. Dual culture techniques showed that the endophytic fungi, Aspergillus terreus, Fusarium solani and Penicillium verrucosum isolated from the medicinal plant Solenostemma arghel inhibited the pathogen growth in variable levels. The extract of ethyl acetate of the endophytic fungal was found to be active against Fusarium solani. The ethyl acetate fractions of Penicillium verrucosum inhibited the pathogen growth by $47 \%$ while $A$. terreus, and $F$. solani showed inhibition percentage of $45 \%$ and $40 \%$, respectively.
\end{abstract}

Keywords: Sweet Melon, Fusarium solani, fruit wilt, Solenostemma arghel

\section{Introduction}

Sweet melon, (Cucumis melo ) is a very important fruit crop cultivated worlwide. The crop is

cultivated in Egypt for local market consumption and exportation. It is known as a very healthful fruit containing vitamins, sugars, folic acid, ascorbic acid and other healthbioactive compounds (Nuangmek et al., 2019). The sweet melon is sensitive to the disease of fusarium rot when cultivated in the same soil without regular rotation (Soriano-Martin et al., 2006). According to Nuangmek et al., (2019), the disease caused by Fusarium species is considered the high prevalent postharvest and preharvest diseases of cucurbit fruits (melon and cucumbers). The melon disease caused by Fusarium species leads to serious economic losses. In addition, the plant pathogen can stay dormant in the soil for many years via the production of chlamydospores, making it very tough to be controlled (Garret, 1970). Many strategies have been used to control this severe pathogen like crop rotation strategy, but completely failed when a disease outbreak occured (Zhao et al., 2011). The alternaive emerging strategy to control Fusarium rot disease is the biological control. Many antagonistic microorganisms and microbial endophytes have been confirmed to be effective as biocontrol agents against many plant pathogens (Bhakthavatchalu and Shivakumar, 2018; Marrez et al., 2019). Many of these endophytes are capable of synthesizing antimicrobial secondary metabolites which act as biocontrol agents (Kamel et al., 2020). Many studies reported that the soil incorporation with fungal antagonists results in reducing the incidence of diseases in different crops (Alwathnani and Perveen, 2012).

The purpose of our study was to isolate and identify the causal agent of the sweet melon fruit rot disease using morphological and molecular teqniques and to evaluate the efficacy of extracts of fungal endophytes isolated from the medicinal plant Solenostemma arghel as biocontrol to the pathogen.

\section{Materials and Methods}

\subsection{Samples collection}

In summer 2019, brown color appeared inside the fruits of the native Sweet Melon (shamam) for the first time in Upper Egypt at Aswan University farm (Aswan city, Egypt). The fruits were collected and kept in bags and then transferred immediately for pathogen isolation.

\subsection{Isolation of the Pathogen from infected fruits of Sweet Melon}

The skin of the sympotomatic part of infected sweet melon was firstly surface sterilized by ethanol (70\%) for 1 min and $\mathrm{NaClO}(1 \%)$ for 1 min then washed four times

\footnotetext{
* Corresponding author. e-mail: fatma.fakhry@aswu.edu.eg.
} 
with sterilized distilled water. Small parts were aseptically cut and plated on potato dextrose agar (PDA) plates for 4 days at $28{ }^{\circ} \mathrm{C}$. Within two days, fungal mycelia were visibly grown from the fruit pieces. Using hyphal tip method for purification, a single hypha was transmitted and inoculated on fresh PDA plates then examined by microscope (Ghuffar et al., 2018).

\subsection{Morphological and Molecular identification}

Isolated fungal species were identified morphologically based on their colonial and hyphal characteristics (Booth, 1977; Christensen and Raber, 1978; Moubasher, 1993; Raper and Fennell, 1965). The pathogen molecular identification was performed by rRNA gene sequencing. CTAB method (Gontia-Mishra et al., 2014) was used to extract DNA from five days incubated cultured fungus. The partial fragment of rDNA gene was amplified by using two fungal primers ITS1 and ITS4 (Suarez et al., 2005). The PCR amplifications were detected by electrophoreses on $1 \%$ agarose gel. These bands were eluted and sequenced in Korea Solgent Company. NCBI Blast website was used to analyze sequences. MEGA6 software programme was used for construction of phylogenetic tree (Tamura et al., 2013).

\subsection{Pathogenicity test}

The re-inoculation test of pathogenicity was done by the method according to Berner et al. (2007), the pathogen was injected on PDA media and incubated at $28{ }^{\circ} \mathrm{C}$ for 11 days. The harvested conidia were suspended in sterilized water at $1 \times 10^{6}$ Conidia/ ml, the sweet melon fruits were sprayed by the conidial suspension then covered with bags and incubated at $28^{\circ} \mathrm{C}$ for two weeks. In the same conditions, the control fruits were sprayed with sterile distilled water.

\subsection{Selection of antagonistic isolates from Solenostemma arghel}

From fungal lab collection from Faculty of Science, Aswan University, endophytic fungi isolated from the medicinal plant, S. arghel (Aspergillus terreus, Fusarium solani and Penicillium verrucosum) (unpublished result) were obtained. Each isolate was sub-cultured on PDA media for their cultivation and allowed to flourish at 28 ${ }^{\circ} \mathrm{C}$.

\subsection{In vitro screening of antagonistic fungi against sweet melon pathogen}

Antagonistic effects of endophytic fungi isolated from S. arghel were tested in vitro against sweet melon pathogen by dual culture assay (Albert et al., 2011). The control plates were made by culturing the pathogenic fungus against agar plug. The tests were done in four replicates and incubated at $28 \pm 2{ }^{\circ} \mathrm{C}$ and the growth diameter of tested pathogen was measured. The inhibition percentage was calculated after 7 days based on the inhibition of colony diameter:

\section{Inhibition (\%)= D1-D2/D1x100}

D1: the colony diameter of the pathogen co-inoculated with agar plug (control), and D2: the pathogen colony diameter coinoculated with fungal endophytes.

\subsection{Extraction of secondary metabolites from endophytic fungi}

Endophytic fungi isolated from $S$. arhgel were incubated as $6 \mathrm{~mm}$ disc in $1000 \mathrm{ml}$ flask containing $400 \mathrm{ml}$ PDA media under shaking condition (210 rpm) along 10 days. Then ethyl acetate (EtOAc) was combined with culture and left 24h under continuous shaking, and then the extract of EtOAc was separated by separating funnel and vacuum dried (Abdel-Motaal et al., 2010).

\subsection{Antifungal activity of endophytic fungi against sweet melon pathogen}

Fungal ethyl acetate extracts were added into PDA at various concentrations $(0.5,1.0$ and $2.0 \mathrm{mg} / \mathrm{ml})$, shaken well to homogenize. The disc of mycelia $(0.8 \mathrm{~cm}$ diameter) was transferred in the center of the plate $(6.0 \mathrm{~cm}$ in diameter) according to the 'poisoned food method' that used to check the antimicrobial effect against the pathogen (Balouiri et al., 2016). According to Singh and Tripathi, (1999), the fungal growth diameters of the treated and control plates were measured after 3 days, and the inhibition percentage was calculated. The minimum inhibitory concentration (MIC) values of each extract for fungal growth were determined in comparison with the control according to Balouiri et al., (2016).

\subsection{Statistical analysis}

All experiments were done in triplicate. One-way analysis of variance (ANOVA) was used to analyze the obtained results with the help of Minitab 18 software (www.minitab.com). Tukey test was run to verify the significant differences between the control and treatments $(\mathrm{P} \leq 0.05)$. Values shown in the figures are the means \pm standard errors (SEs).

\section{Results}

\subsection{Examined symptoms}

Sweet melon fruits showed the typical rot symptoms on the base of the fruits in which the fissures are found as white mycelia present in the epidermal tissue (Fig. 1A). A cross section through a mature lesion showed brown and spongy internal rot with a light brown halo (Fig. 1B).

\subsection{Morphological characterisation of the pathogen}

Colonies of the examined fungi were cottony white color (Fig 1C) with hyalline hyphae, and the mycelium became yellowish white and its reverse is yellow-brown. Fusarium solani has aerial hyphae that grow to form conidiophores which branch into monophialides which produce conidia. Phialids were more or less erect. The macroconidia were slightly curved; hyaline and have three septa but may have as many as 4-5. Microconidia were oval or cylindrical, hyaline, smooth and absecnce of septa, but sometimes they may have one or two. Chlamydospores also forms by $F$. solani that most usually emerged under suboptimal growth conditions (Fig. 1D, 1E, 1F, 1G). This fungus was identified as $F$. solani according to morphological characteristics, (Summerbell, 2003; Chehri et al., 2015). 
3.3. Molecular characterisation of sweet melon pathogen

To confirm the morphological identification, $F$. solani was exposed to a genomic DNA extraction and gene amplification. The partial 28S nrDNA gene and internal transcribed spacer region (ITS) were amplified by using primers ITS1 and ITS4 (Suarez et al., 2005; White et al., 1990). According to the NCBI-BLAST analysis, the ITS sequence showed 97-100\% similarity with all F. solani (LC70340.1, MF359555.1, JN786598.1) in the Phylogenetic tree (Fig. 2). The ITS sequences of $F$. solani were placed in the Gen Bank database with accession number LC510255.

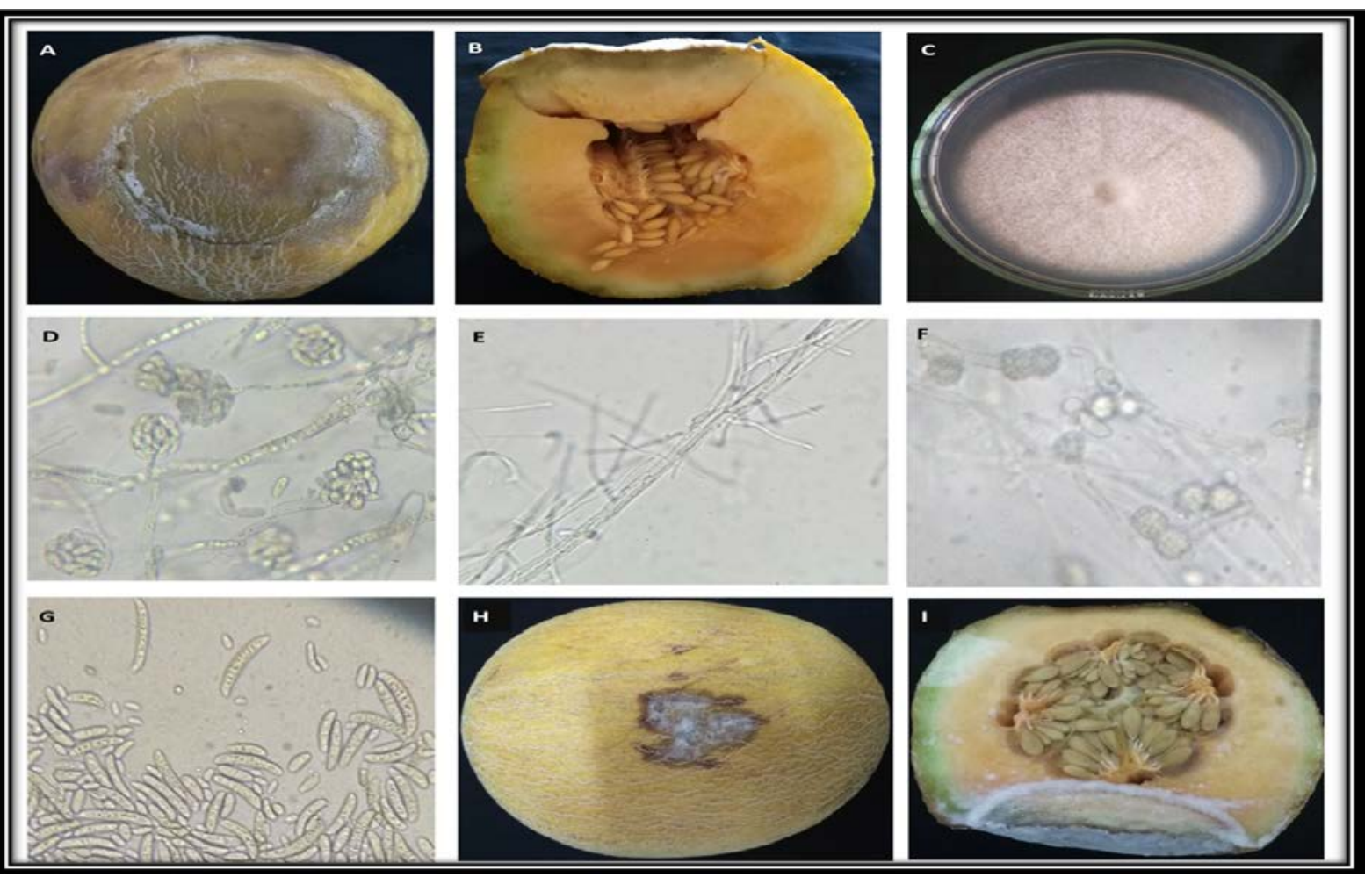

Figure 1. Fruit rot symptoms on Sweet Melon after natural infection by Fusarium solani. (A,B) Natural disease symptoms on Sweet Melon fruit. (C) Colony shape. (D) False head. (E) Phialids. (F) chlamydospores. (G) Macro and Micro-conidia. (H, I) Pathogenicity re-test using isolated Fusarium solani on Sweet Melon. (Cucumis melo) fruits one week after inoculation.

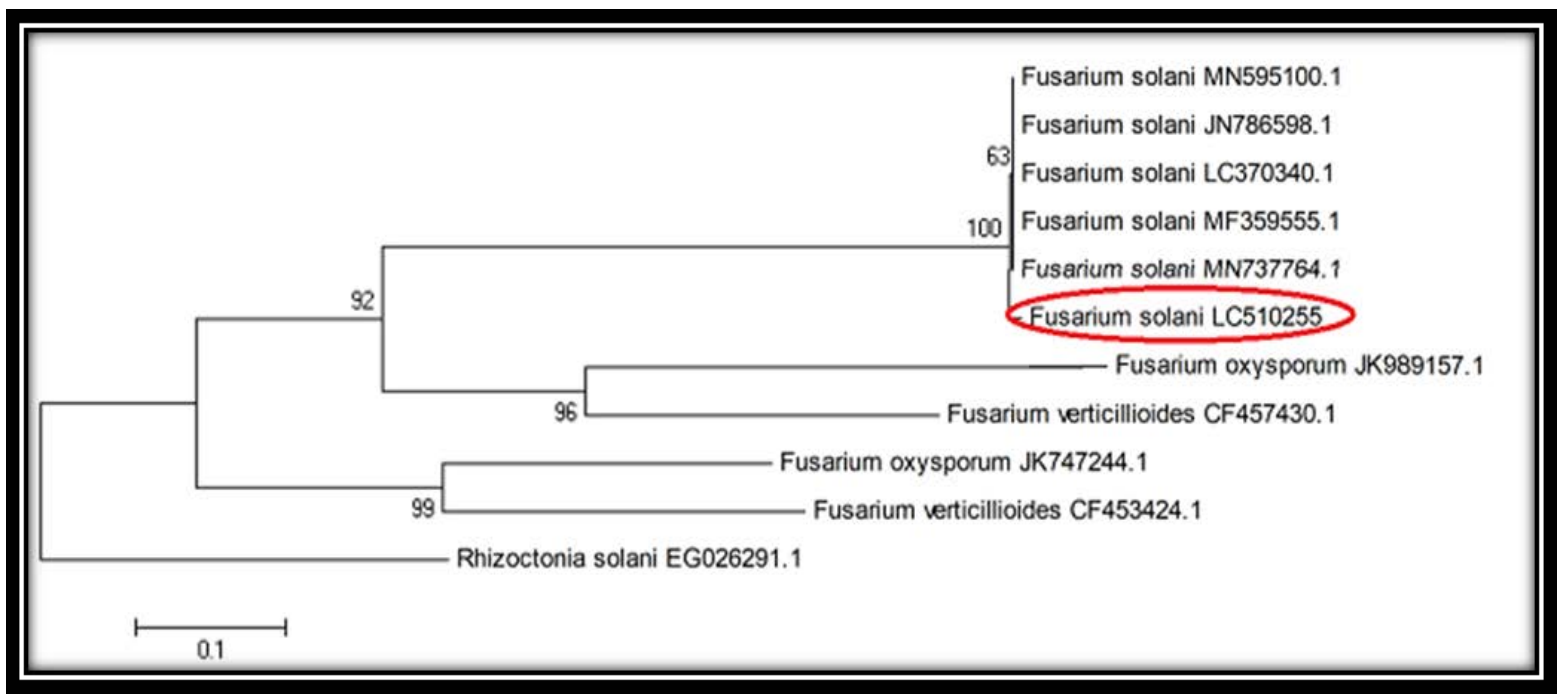

Figure 2. Phylogenetic relationships of partial sequences of rRNA gen from Fusarium solani fungal pathogenic and selected fungi derived from NCBI Genbank. The construction of phylogenetic tree represents Neighbor-joining method using MEGA 6 software.

\subsection{Pathogenicity test}

When the healthy fruits of sweet melon were sprayed with $F$. solani, the symptoms of disesae appeared after one week as a white spots, that turned to brown after two weeks (Fig. 1H, 1I) while control fruits did not show any morphological symptoms. Fusarium solani was reisolated from the parts of diseased fruits but not from the control fruits. 
3.5. Antagonist activity of Solenostemma arghel endophytes against sweet melon pathogen

The dual culture assay demonstrated that the tested endophytic fungi obtained from S. arghel (Aspergillus terreus, Fusarium solani and Penicillium verrucosum) inhibited the growth of $F$. solani (the sweet melon pathogen). Figure (3) showed that the antagonistic isolates change the shape of phytopathogen colonies from circular as in control to elongated ellipse. In comparison with the control, the above mentioned isolates had a significant inhibition effect $(p<0.05)$ on the growth of pathogen colonies. The antagonistic activity of the selected endophytic fungi showed varying degrees of inhibition against the phytopathogenic $F$. solani, the highest inhibition percentage demonstrated by $F$. solani followed by $A$. terreus and $P$. verrucosum with inhibition percentage (35\%, 26.1\% and 22.7\%), respectively (Fig. 3).

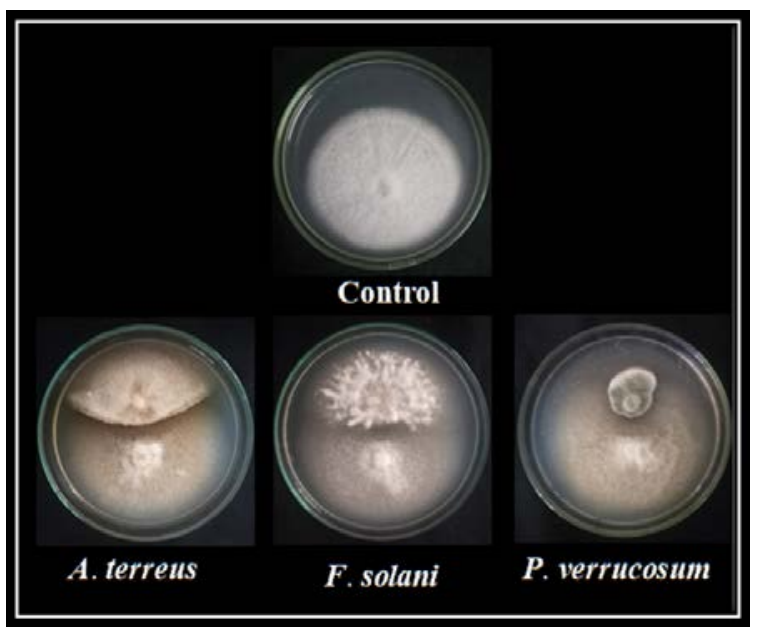

Figure 3. Antagonistic activity of $S$. arghel fungi against the pathogen F. solani.

\subsection{Antifungal activity of endophytic fungi against sweet} melon pathogen

The antifungal activities of selected endophyte had a significant efficacy against sweet melon pathogen (Fig. 4).

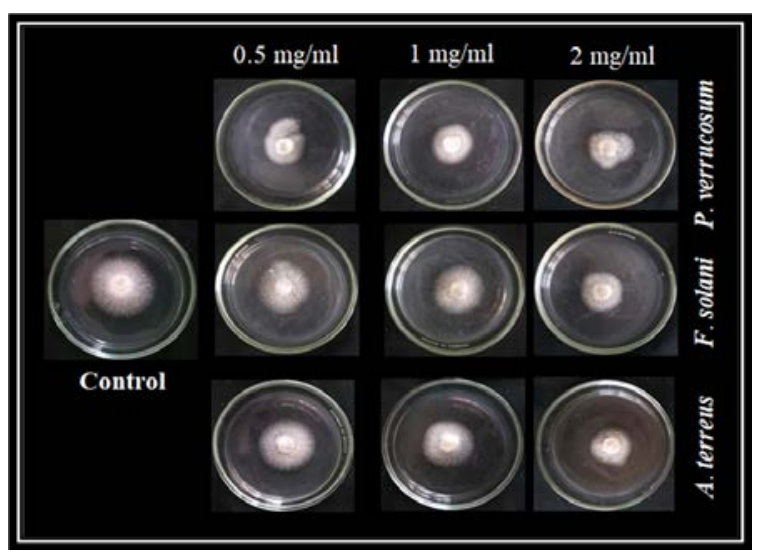

Figure 4. Antifungal activity of $S$. arghel endophytic fungal extracts against $F$. solani (the sweet melon pathogen).

The growth inhibition percentage of $F$. solani by various extract concentrations $(0.5,1.0$ and $2.0 \mathrm{mg} / \mathrm{ml})$ of $S$. arghel endophytes was determined by measuring the inhibition zones diameter. The concentrations of the selected fungal endophytes were active significantly $(p<0.05)$ against the sweet melon pathogen with variable inhibitory effects. In Figure (5), Penicillium verrucosum produced the most active substances in the EtOAc fraction which showed the best antifungal activity at concentration $2.0 \mathrm{mg} / \mathrm{ml}\left(\mathrm{MIC}_{47}\right)$ and at $0.5 \mathrm{mg} / \mathrm{ml}$, the inhibition percentage was $41.6 \%$. Aspergillus terreus and F. solani exhibited antifungal activity against the pathogenic fungi

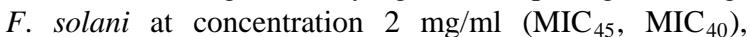
respectively (Fig. 5).

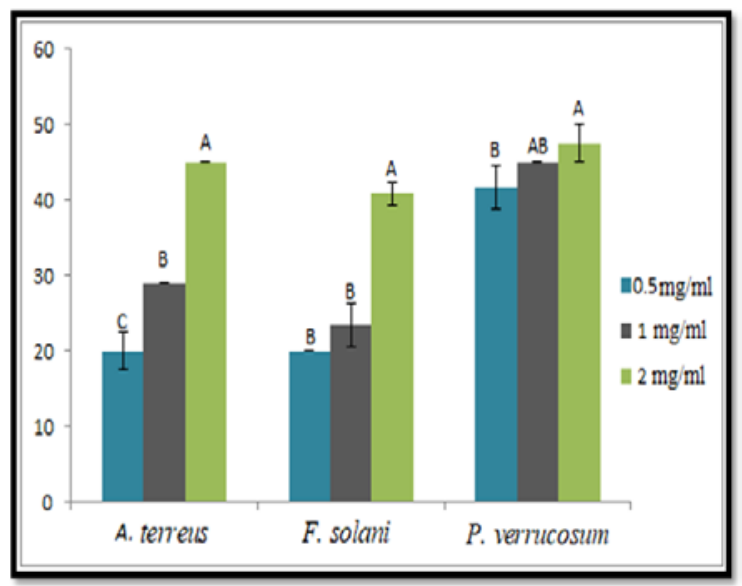

Figure 5. Histogram showing the antifungal activity of S. arghel endophytic fungi against Fusarium solani, values are mean \pm stander errors (SEs) of three independent replicates $(n=3)$. Letters $a, b$ and $c$ indicate significant differences $p<0.05$ (ANOVA after Tukey's test analysis).

\section{Discussion}

Rot disease caused by Fusarium species is severe for many crops. It is a very common disease of cucurbit fruits during preharvest and postharvest time according to Nuangmek et al., (2019). Our results reported that $F$. solani is the causal agent of fruit rot disease to sweet melon in this study. Fusarium solani was reported as a predominant factor in rotting mature melon fruits under wet weather conditions in Texas (Toussoun and Snyder1961). Vast isolates of $F$. solani obtained from roots of muskmelon plants showed root-rot symptoms (Champaco, 1990). Also, other Fusarium species like F. equiseti have been recorded as a causal agent of fruit rot of cantaloupes by Kim and Kim, (2004) and F. incaratum caused fruit rot to muskmelon (Wonglom and Sunpapao, 2020). To reduce losses caused by Fusarium to sweet melon fruits, control actions are currently subjected to research. In the present study, the above-mentioned endophytic fungi considerably inhibited the growth of the phytopathogenic Fusarium in vitro. They were effective as biological control agents against the sweet melon pathogen. Previous researches reported that several antagonistic species have been confirmed to be effective as bio-control agents in controlled laboratory conditions (Zhao et al., 2011), like Peniciliium species (Sabuquillo et al., 2006), Aspergillus species (Kandhari et al., 2000) and $F$. solani which isolated from cotton plants as endophytic fungi (Wei et al., 2019).

Our results clearly show that $S$. arghel endophytes affected the growth of the phytopathogenic fungus $F$. solani. This inhibition is propably attributed to the secretion of phytoanticipins or other inhibitory substances produced by antagonists such as aspergillic acid and 
dermadin. This inhibition differs according to the nature, quantity and quality of antibiotics/inhibitory substances (Alwathnani and Perveen, 2012). Purification of active molecules may enhance the biocontrol process through the increase in the inhibition percentage compared to the crude extract.

\section{Conclosion}

Fusarium solani is the causal agent of fruit rot disease of Sweet Melon. Biological control of $F$. solani by friendly endophytic fungi, Aspergillus terreus, Fusarium solani and Penicillium verrucosum isolated from the medicinal plant Solenostemma arghel inhibited the growth of the pathogen at a variable manner. These fungal endophytes can be used as biocontrol agents to supress the Fusarium pathogenicity.

\section{References}

Abdel-Motaal FF, El-Sayed M, El-Zayat S, Nassar MM and Ito S. 2010. Choanephora rot of floral tops of Hyoscyamus muticus caused by Choanephora cucurbitarum. J Gen Plant Pathol, 76: 358-361.

Albert S, Chauhan D, Pandya B and Padhiar A. 2011. Screening of Trichoderma spp. as potential fungal partner in co-culturing with white rot fungi for efficient biopulping. Global J Biotechnol Biochem, 6: 95-101.

Alwathanani AH and Perveen K. 2012. Biological control of fusarium wilt of tomato by antagonist fungi and cyanobacteria. Afr J, 11: 1100-1105.

Azevedo LJ, Pereira OJ and Araujo LW. 2000. Endophytic microorganisms: a review on insect control and recent advances on tropical plants. EJB, 3: 15-16.

Balouiri M, Sadiki M and Ibnsouda KS. 2016. Methods for in vitro evaluating antimicrobial activity: a review. J Pharm Anal, 6: 71-79.

Berner DK, Smallwood EL, McMahon MB and Luster DG. 2007. First report of leaf spot caused by Cladosporium herbarum on Centaurea solstitialis in Greece. Plant Dis, 91: 463.

Bhakthavatchalu S and Shivakumar S. 2018. The influence of physicochemical parameters on phosphate solubilization and the biocontrol traits of Pseudomonas aeruginosa FP6 in phosphatedeficient conditions. Jordan J Biol Sci, 11:215-221.

Booth C. 1977. Fusarium. Laboratory guide to the identification of major species. Mycologia, 69:1239.

Chehri K, Salleh B and Zakaria L. 2015. Morphological and Phylogenetic Analysis of Fusarium solani Species Complex in Malaysia. Microb Ecol, 69: 457-471.

Christensen M and Raber BK. 1978. Synoptic key to Aspergillus nidulans group species and related Emericella species. Trans $\mathrm{Br}$ Mycol Soc, 71: 177-191.

Garret SD. 1970. Pathogenic Root-Infecting Fungi. Cambridge University Press, London, UK.

Ghuffar S, Irshad G, Naz F, Rosli HB, Hyder S, Mehmood N, Zeshan MA, Mayer CG and Gleason ML. 2018. First report of two Penicillium spp. causing post-harvest fruit rot of grapes in Pakistan. Plant Dis, 104: 1037.

Gontia-Mishra I, Tripathi N and Tiwari SA. 2014. Simple and rapid DNA extraction protocol for filamentous fungi efficient for molecular studies. IJBT, 13: 536-539.
Kamel NM, Abdel-Motaal FF and El-Zayat SA. 2020. Endophytic fungi from the medicinal herb Euphorbia geniculata as a potential source for bioactive metabolites. Arch Microbiol, 202: 247-255.

Kandhari J, Majumder S and Sen B. 2000. Impact of Aspergillus niger AN27 on growth promotion and sheath blight disease reduction in rice. Int Rice Res Notes, 25: 21-22.

Kim JW and Kim HJ. 2004. Fusarium fruit rot of posthavest oriental melon (Cucumis melo L. var. makuwa Mak.) caused by Fusarium spp (in Korean with English summary). Res Plant Dis, 10: $260-267$.

Marrez DA, Abdel-Rahman GN and Salem SH. 2019. Evaluation of Pseudomonas fluorescens Extracts as Biocontrol Agents Against some Foodborne Microorganisms. Jordan J Biol Sci, 12: 535-541.

Moubasher AH. 1993. Soil fungi in Qatar and other Arab countries.The scientific and applied research center. University of Qatar, Doha

Nuangmek W, Aiduang W, Suwannarach N, Kumla J, Kiatsiriroat $\mathrm{T}$ and Lumyong S. 2019. First report of fruit rot on cantaloupe caused by Fusarium equiseti in Thailand. J Gen Plant Pathol, 85: 295-300.

Raper KB and Fennell DI. 1965. The genus Aspergillus. Williams \& Wilkins Co, Baltimore.

Sabuquillo P, De Cal A and Melgarejo P. 2006. Biocontrol of tomato wilt by Penicillium oxalicum formulations in different crop conditions. Biol Control, 37: 256-265.

Singh J and Tripathi NN. 1999. Inhibition of storage fungi of blackgram Vigna mungo by some essential oils. Flavour Frag J, 14:1-4.

Soriano-Martın ML, Porras-Piedra A and Porras-Soriano A. 2006. Use of microwaves in the prevention of Fusarium oxysporum $\mathrm{f}$. sp. melonis infection during the commercial production of melon plantlets. J Crop Prot, 25: 52-57.

Suarez MB, Walsh K and Boonham N. 2005. Development of realtime PCR (Taq-Man) assays for the detection and quantification of Botrytis cinerea in planta. Plant Physiol Bioch, 43: 890-899.

Summerbell R. 2003. 'Ascomycetes: Aspergillus, Fusarium, Sporothrix, Piedraia, and Their Relatives', in Pathogenic Fungi in Humans and Animals (2nd ed.), ed. D.H. Howard, New York: Marcel Dekker, pp. 361-368.

Tamura K, Stecher G, Peterson D, Filipski A, and Kumar S. 2013. MEGA6: Molecular

Evolutionary Genetics Analysis version 6.0. Mol Biol and Evol, 30: $2725-2729$.

Toussoun TA and Snyder WC. 1961. The pathogenicity, distribution, and control of two races of Fusarium (Hypomyces) solani f. cucurbitae. Phytopathology, 51:17-22.

Wei F, Zhang Y, Shi Y, Feng H, Zhao L, Feng Z and Zhu H. 2019. Evaluation of the Biocontrol Potential of Endophytic Fungus Fusarium solani CEF559 against Verticillium dahliae in Cotton Plant. Biomed Res Int, 3: 1-12.

White TJ, Bruns T, Lee S and Taylor JW. 1990. Amplifcation and direct sequencing of fungal ribosomal RNA genes for phylogenetics. PCR protocols: a guide to methods and applications. Academic Press Inc., New York, 315-322.

Wonglom P and Sunpapao A. 2020. Fusarium incarnatum is associated with postharvest fruit rot of muskmelon (Cucumis melo). J Phytopathol, 168: 204-210.

Zhao Q, Dong C, Yang X, Mei X, Ran W, Shen Q and Xu Y. 2011. Biocontrol of Fusarium wilt disease for Cucumis melo melon using bio-organic fertilizer. Appl Soil Ecol, 47: 67-75. 